\title{
Study on Physico-chemical Properties of Oil and Powder of Date Palm Seeds (Phoenix dactylifera)
}

\author{
M. Kirthy Reddy ${ }^{*}$, H. Durga Rani, Ch. Naga Deepika, Suraj Samrawat, \\ V. Akshara and K. Rajesh \\ Department of Food Processing Technology, College of Food Science and Technology, \\ Bapatla, Guntur, Andhra Pradesh - 522101, India \\ *Corresponding author
}

\section{A B S T R A C T}

\begin{tabular}{|l|}
\hline Ke y w o r d s \\
$\begin{array}{l}\text { Date seeds, Date } \\
\text { seed oil, Date seed } \\
\text { powder, Deffated } \\
\text { date seed oil, Fatty } \\
\text { acid profile, Bio } \\
\text { diesel. }\end{array}$ \\
\hline Article Info \\
\hline $\begin{array}{l}\text { Accepted: } \\
\text { 07 October } 2017 \\
\text { Available Online: } \\
\text { 10 December } 2017\end{array}$ \\
\hline
\end{tabular}

\section{Keywords}

Date seeds, Date powder, Deffated date seed oil, Fatty acid profile, Bio

Accepted:

07 October 2017 10 December 2017
Date palm seeds (Phoenix dactylifera) are discarded as waste after utilization of date flesh by the industries. But the oil from date seed is reported to be rich in unsaturated fatty acids, phenols and tocopherols. Whereas, the date seed powder (DSP) contains high protein and fibre content. Among all the treatment (Control, Soaking, Soaking + Roasting, Roasting) control sample showed highest oil yield $(8.2 \%)$ was observed. The total fat content in the DSP was $10.7 \%$, Protein $(5.5 \mathrm{~g} / 100 \mathrm{~g})$ and Total dietary fiber $(57.24 \%)$, with $52.7 \%$ of it was insoluble dietary fiber. The date seed oil is rich in unsaturated fatty acids with oleic acid as the predominant one $(51.456 \%)$ followed by palmitic acid $(12.831 \%)$, Myristic acid $(10.447 \%)$, Lauric acid (10.363\%), Linoleic acid (7.20\%) and Stearic acid $(6.56 \%)$. The percent of FFA (Free Fatty Acids) was $(0.9 \%)$. The low peroxide value of 1.243 meq $\mathrm{O}_{2} / \mathrm{kg}$ indicates that date seed oil is fresh and is less susceptible to autoxidation. The iodine value is $73.60 \mathrm{~g}$ Iodine $/ 100 \mathrm{~g}$. The high saponification value of $208.33 \mathrm{mg} \mathrm{KOH} / \mathrm{g}$ of oil indicates very high content of low molecular weight triacylglycerol, which is an desirable property to use such oil as bio diesel.The best oil yeild was satisfactory at $2 \mathrm{~h}$ extraction time and 2000 microns mesh size by using soxhelt extractor and petroleum ether as solvent.

\section{Introduction}

Date seeds, also called stones or pits, form part of the integral date fruit, which is composed of a fleshy pericarp and seed that constitutes between $10 \%$ and $18 \%$ of the date fruit's weight, depending on the variety and quality (Hussein et al., 1998); thus, approximately $12,25,000$ tons of date seeds are produced annually (FAO, 2016). As it is also known that date seeds contain valuable bioactive compounds, utilization of this byproduct is highly desirable for the date industry. The seeds are often used as animal feed-stuff (Ahmed et al., 1995), propagation of date palms, and other industrial applications. The palm pit oil contains a certain percentage of pale yellowish-green oil with pleasant odor (Shahidi, 2005).

The palm kernel oil is used for several applications like a liniment for indolent tumors (Graham et al., 2000), and showed antimicrobial effects against some microorganisms like Escherichia coli, hemolytic Streptococci, Aspergillus fumigatus 
and Staphylococcus aureus (Barmak, 2011. It is a rich source of some minerals, especially iron content, total sugars and crude fats (AlShahib and Marshall, 2003), large quantities of fiber, and possibly resistant starch (Ekwenye and Ijeomah, 2005).

As the protein and fibre sources which are available in the present era are more expensive. This has led to the investigation of alternative nutritive sources for food use which can be used to either partially or fully replace more expensive ones. There is also an advantage in using non-utilized by products that were considered to be waste to recover useful functional nutrients. One such waste product from food industry is Date Seed. As Date Seed contains considerable amounts of proteins, dietary fibre and oil. Keeping this in view present research was under taken with the objective of extracting the oil from date seed and studying the oil characteristics and fatty acid profile along with evaluating physico-chemical properties of defatted date seed powder.

\section{Materials and Methods}

\section{Raw material and processing}

Semi dry dates were procured from local market of Bapatla, Guntur District, Andhra Pradesh, India. Date seeds are manually removed pulverized to a mesh size of 2000 microns. After manually separating the date seeds they are subjected to different treatments (Control, Soaking, Soaking + Roasting and Roasting). Then the pulverized date seeds were subjected for oil extraction in Soxhelt Apparatus.

Physico chemical analysis of date seed oil and defatted date seed powder

The Date palm seed oil and powder extracted were evaluated for their physico-chemical analysis namely, moisture content, carbohydrates, reducing sugars, protein, fat, Phenolic compounds, crude fiber, ash content, tocopherol, peroxide value, iodine value, acid value, saponification value and unsaponification value.

\section{Moisture content}

The moisture content of date palm seed powder was determined by air oven drying method by placing about $2 \mathrm{~g}$ of sample for 24 $\mathrm{h}$ in an air oven maintained at $103 \pm 1{ }^{\circ} \mathrm{C}$ (AOAC, 1980).

\section{Total carbohydrate}

The Total Carbohydrate content can be measured by Phenol Sulphuric Acid method

Absorbance corresponds to $0.1 \mathrm{~mL}$ of the test $=\mathrm{x} \mathrm{mg}$ of glucose

$100 \mathrm{~mL}$ of the sample solution contains = $\mathrm{x} / 0.1 * 100 \mathrm{mg}$ of glucose

\section{Fat content by soxhlet method}

The fat content of the samples is estimated by Soxhlet method (AOAC, 1980)

(Final weight of beaker -

Weight of empty beaker) $* 100$

Fat content $(\%)=$

Weight of sample

\section{Protein content}

The protein content is measured by using Micro Kjeldahl method

$(\mathrm{ml} \mathrm{HCl}-\mathrm{ml}$ Blank $) *$ Normality $* 14.01$

Nitrogen $\mathrm{g} / \mathrm{kg}=$

Weight of the sample

Protein $=$ Nitrogen $* 6.25$ 


\section{Crude fiber}

$\left(\mathrm{w}_{2}-\mathrm{w}_{1}\right)-\left(\mathrm{w}_{3}-\mathrm{w}_{1}\right) * 100$

$$
\text { Weight of the sample }
$$

\section{Ash content}

Ash content of the sample was done in muffule furnance

\section{Iodine value}

The Iodine value is a measure of the degree of unsaturation in oil. It is constant for a particular oil.

Iodine value is a useful parameter in studying oxidative rancidity of oils since higher the unsaturation the grater the possibility of oils to go rancid.

Iodine value/ number was defined as the ' $\mathrm{g}$ ' of iodine absorbed by $100 \mathrm{~g}$ of oil.

Iodine number $=\frac{12.69(\mathrm{~B}-\mathrm{S}) \mathrm{N}}{\mathrm{g} \text { Sample }}$

Where,

$\mathrm{B}=\mathrm{mL}$ thiosulphate for blank, $\mathrm{S}=\mathrm{mL}$ thiosulphate for sample

$\mathrm{N}=$ Normality of thiosulphate solution

\section{Acid value}

A small quantity of free fatty acids is usually present in oils along the triglycerides. Free fatty acid content is known as acid number/ acid value. It increases during storage. Keeping quality of oil, therefore, release upon the free fatty acid content. Acid number was defined as $\mathrm{mg}$ of $\mathrm{KOH}$ required to neutralize the free fatty acids present in $1 \mathrm{~g}$ of sample.
Titre value X Normality of KOH X 56.1 Acid value $=$

Weight of the sample (g)

\section{Saponification value}

Saponification is the process by which the fatty acids in the glycerides of the oil are hydrolysed by an alkali.

Saponification value is the amount $(\mathrm{mg})$ of alkali required to saponify a definite quantity $(1 \mathrm{~g})$ of oil. This value is useful for comparative study of the fatty acid chain length in oils.

Saponification value $=$

28.05 X (Titre value of blank Titre value of sample)

Weight of the sample $(\mathrm{g})$

\section{Peroxide value}

Peroxide value is a measure of the peroxides contained in the oil. The peroxides present are determined by titration against thiosulphate in the presence of KI. Starch is used as indicator.

Peroxide value $=$ S X N X 100

Where, $\mathrm{S}=\mathrm{mL}$ sodium thiosulphate (Test blank) and $\mathrm{N}=$ Normality of sodium thiosulphate

\section{Phenols}

Phenols react with phosphomolybdic acid in Folin - Ciocalteau reagent in alkaline medium and produce blue colored complex (molybdenum blue).

From the standard curve, the concentration of phenols in the test sample is expressed as $\mathrm{mg}$ phenols/100g material. 


\section{Tocopherols}

Tocopherols can be estimated after Emmerie - Engel reaction. This is based on the reduction of ferric to ferrous ion, by tocopherols, which then forms a red color with 2,2,'dipyridyl reagent. Tocopherol is first extracted into xylene and read at $460 \mathrm{~nm}$; a correction is made after adding ferric chloride and read at $520 \mathrm{~nm}$.

Amount of tocopherol in $\mu \mathrm{g} / \mathrm{g}$ of tissues $=\mathrm{OD}$ at $520 \mathrm{~nm}-\mathrm{OD}$ at $460 \mathrm{~nm} * 0.29 * 15 *$ Total volume of homogenate/Reading of standard at $520 \mathrm{~nm} *$ volume used $*$ Weight of tissue

\section{Unsaponification}

Unsaponifiable matter represents substances which are insoluble or are incapable of forming soaps with alkali. In edible oils, it is present upto $1-2 \%$.

The crystals of unsaponifiable matter are observed for the presence of this steroid to know the animal or plant origin of the oil. In the method, the oil is saponified with alcoholic $\mathrm{KOH}$ and then extracted with petroleum ether. The extract is washed with alcohol and water, evaporated and weighed. Unsaponifiable matter is represented as difference between the weight of the residue and the fatty acids content of it (determined by $\mathrm{NaOH}$ titration in alcoholic medium).

Amount of fatty acids in extract $=\mathrm{B}$

$\mathrm{B}$ as oleic acid $=0.282 \mathrm{X} \mathrm{V} \mathrm{X} \mathrm{N}$

Where,

$\mathrm{V}=$ Titration reading,

$\mathrm{N}=$ Normality of $\mathrm{NaOH}$

Percentage of unsaponifiable matter = $100\left(\mathrm{~W}_{1}-\mathrm{B}\right) / \mathrm{W}_{2}$
Where,

$\mathrm{W}_{2}=$ wt. of sample

$\mathrm{W}_{1}=\mathrm{wt}$. of residue.

\section{Results and Discussion}

\section{Oil extraction}

Oil from Date palm seed was extracted by using different combinations of soaking and heating procedures. Among all the treatments control sample showed highest oil yield of $8.2 \%$ followed by $\mathrm{T}_{3}$-Roasting $(7.9 \%)$ and $\mathrm{T}_{1}$ - Soaking (7.8\%) and least oil (7.2\%) yield was obtained in $\mathrm{T}_{2}=$ Soaking + Roasting (7.2\%) sample.

\section{Effect of particle size}

It has been noticed that the decrease in particle size leads to increase of oil yield. This manner is expected because of the increased surface area of grounded seed. For this reason, the contacted area between seed and solvent increased, and the mass transfer of oil from the solid phase to the liquid phase increased accordingly. Also, the time needed for the solvent to diffuse inside the small particle seed is lower than large particle. Highest oil yield $(8.2 \%)$ was observed in seed powder having mesh size of 2000 microns.

\section{Physico chemical properties of date seed powder}

Initial Moisture Content of the DSP was 4.8\% and after extraction of oil from the DSP, DDSP recorded a moisture content of 6.5\% this may be due to the presence of traces of solvent in DDSP.

Fat content in the DSP was $10.7 \%$, after oil extraction by soxhlet apparatus using petroleum ether as solvent the oil residue present in DDSP was $2.55 \%$. On the other 
hand, protein also had been detected to be present in date seed in considerable amount of $5.5 \mathrm{~g} / 100 \mathrm{~g}$ in DSP and $5.32 \mathrm{~g} / 100 \mathrm{~g}$ in DDSP. The total dietary fiber found in date seed was $57.24 \%$, with $52.7 \%$ of it was insoluble dietary fiber namely as hemicelluloses, cellulose and lignin (Al-Farsi and Lee, $2008 \mathrm{~b})$. The carbohydrate present in DSP is $78.3 \%$ and that of DDSP is found to be $76.8 \%$, this could be due to the presence of sugars like sucrose and invert sugar. The total sugars in DSP is $4.50 \mathrm{~g} / 100 \mathrm{~g}$ which accounts to be $2.46 \mathrm{~g} / 100 \mathrm{~g}$ of reducing sugars and 1.98 $\mathrm{g} / 100 \mathrm{~g}$ of non-reducing sugars whereas the total sugars in DDSP is $4.01 \mathrm{~g} / 100 \mathrm{~g}$ of which the reducing sugars accounts to be $2.23 \mathrm{~g} / 100$ $\mathrm{g}$ and the non-reducing sugars to be 1.78 $\mathrm{g} / 100 \mathrm{~g}$. This could be due to the presence of appreciable amount of free aldehydes and ketone groups present in the date seed powder.

\section{Chemical properties of date seed oil}

The percent of FFA (Free Fatty Acids) (0.9\%) and its value of $1.83 \mathrm{mg} \mathrm{KOH} / \mathrm{g}$ is very low due to its high content of unsaturated fatty acids. Low FFA indicates that the oils contain a small amount of free fatty acids, and this could be perhaps due to the small exposure of the seeds to the air during the maturity of the fruits of the dates. The low free fatty acid
(FFA) content of the oil shows that it is edible and could have a long shelf life when compared with many other edible oils.

The saponification value gives an indication on the nature of the fatty acids, which contains the fat and that depends on the average molecular weight of these fatty acids. The high saponification value of $208.33 \mathrm{mg}$ $\mathrm{KOH} / \mathrm{g}$ of oil indicates very high content of low molecular weight triacylglycerol, which is an desirable property to use such oil as bio diesel. The high saponification value of date seeds oil indicates that the fatty acids present in the oil have high number of carbon atoms. This means that date seeds oil, after hydrogenation, could be substituted for some conventional oils.

The low peroxide value of $1.243 \mathrm{meqO}_{2} / \mathrm{kg}$ indicates that seed oil is fresh and is less susceptible to autoxidation. These variations can arise from different factors such as the degree of unsaturation of the fatty acids present in the particular oil, storage, exposure to light, and the content of metals or other compounds that may catalyze the oxidation processes (Choe and Min, 2006). In general, the date seeds oil can be considered as safe for human consumption, because of its low peroxide value that is less than 30 meq peroxide/kg (Gotoh and Wada, 2006).

Table.1 Fatty acid profile of date seed oil

\begin{tabular}{|l|l|l|l|}
\hline Retention time (min) & Identified compounds & Saturation & Weight (\%) \\
\hline 1.773 & Capric acid & $\mathrm{C} 10: 0$ & 0.713 \\
\hline 1.9 & Lauric acid & $\mathrm{C} 12: 0$ & 10.363 \\
\hline 2.13 & Tridecanoic acid & $\mathrm{C} 13: 0$ & 0.103 \\
\hline 2.311 & Myristic acid & $\mathrm{C} 14: 0$ & 10.447 \\
\hline 2.557 & Pentadecenoic acid & $\mathrm{C} 15: 0$ & 0.068 \\
\hline 2.883 & Palmitic acid & $\mathrm{C} 16: 0$ & 12.831 \\
\hline 3.338 & Heptadecanoic acid & $\mathrm{C} 17: 0$ & 0.14 \\
\hline 3.922 & Oleic acid & $\mathrm{C} 18: 1$ & 51.456 \\
\hline 4.613 & Stearate acid & $\mathrm{C} 18: 0$ & 5.56 \\
\hline 4.766 & Linoleic acid & $\mathrm{C} 18: 2$ & 7.20 \\
\hline
\end{tabular}


Iodine value is a measure of the unsaturation of fats and oils and is expressed in terms of the number of gram of iodine absorbed per 100 gram sample. The iodine values of (73.60g Iodine $/ 100 \mathrm{~g}$ ) indicate that this oil is non-drying, highly unsaturated oil. Since the iodine value of date seed oil is lower than 100 it could only be classified as a non-drying oil.

Among 10 fatty acids that were detected Oleic acid was the predominant one $(51.456 \%)$ followed by palmatic acid (12.831\%), Myristic acid (10.447\%), Lauric acid $(10.363 \%)$, Linoleic acid $(7.20 \%)$ and Stearic acid $(6.56 \%)$ which composed together more than $90 \%$ of the total oil.

Generally, oils with high oleic fatty acid contents showed good flavour and frying stability. Oleic fatty acid is beneficial to health due to its low saturation level, minimal trans-isomer level and its potential to reduce LDL cholesterol in the blood as well as high oxidative stability.

The vitamin E content in date palm seed was reported as $6.946 \mu \mathrm{g} / \mathrm{g}$ which is a fat soluble vitamin. Medically, vitamin $\mathrm{E}$ is a potent antioxidant that protects the body against oxidation reactions (radicals) that damage membranes cholesterol transporting lipoproteins. Other medical use cover activity as screening reagent protecting against skin damage and aging by UV radiation, inhibits growth of cancer cells and a protector against at hero sclerosis by lowering cholesterol level.

Biodiesel is assumed as an alternative to conventional diesel. Normally biodiesel is made from vegetable oil, which has few advantages than the diesel in terms of chemical and physical properties such as being biodegradable, non-toxic, its renewability, better gas release, and it yields particles, smoke and carbon monoxide at lower level. In biodiesel production, the oil will react with alcohol such as methanol to produce methyl ester, which is known as biodiesel (Van Gerpen, 2005).

Many oils shows that with high free fatty acid content will result in more catalyst needed (potassium hydroxide $(\mathrm{KOH})$ or sodium hydroxide $(\mathrm{NaOH})$ in order to balance the acidity of the oil. This would become as an advantage for the date seed oil as the free fatty acid content in this oil is very low $(0.9 \%)$. The high saponification value of $208.33 \mathrm{mg} \mathrm{KOH} / \mathrm{g}$ of oil indicates very high content of low molecular weight triacylglycerol, which is an desirable property to use such oil as bio diesel.

Date seed oils had a low refractive index indicating that they may contain fatty acids with medium-short hydrocarbon chains. Viscosity of date seed oil is one of the lowest among most vegetable oils but similar to that of olive oil. This is also an indication to use date seed oil as biodiesel.

The oil extracted from palm seeds is very much similar to other bio oils in chemical composition and basic fuel properties. The best oil yeild was satisfactory at $2 \mathrm{~h}$ extraction time and 2000 microns mesh size by using soxhelt extractor and petroleum ether as solvent.

\section{References}

Ahmed, I.A. and Ahmed, A.W.K. 1995. Chemical composition of date varieties as influenced by the stage of ripening. Food Chemistry. 54: 305-309.

Al farsi, M.A. and Lee, C.H. 2008. Nutritional functional properties of dates: a review. Critic. Rev. Food.Sci.Nutr. 48(10): 877-887.

Al-Shahib, W and Marshall, R.J. 2003. The fruit of the date palm: it's possible use as the best food for the future. 
International Journal of Food Sciences and Nutrition. 54(4): 247-259.

AOAC. 1980. Association of Analytical Chemistry (AOAC). Official Methods of Analysis. Washington, DC.

Barmak, A., Hajeb, P., Rezaei, Y., Akbarzadeh, S. and Mohebbi, G.H. 2011. Oxidative stability of edible oils imported to Iran. Americ. Eur. J. Agric. Environ. Sci. 11(1):34-37.

Choe, E.and Ming, D.B. 2006. Mechanisms and Factors for Edible Oil Oxidation. Comprehensive Reviews in Food Science and Food Safety. 5:169-186.

Ekwenye, U.N. and Ijeomah, C.A. 2005. Antimicrobial effects of palm kernel oil and palm oil. KMITL Science and technology Journal. 5(2): 502-505.

Gotoh, N. and Wada, S. 2006. The importance of peroxide value in assessing food quality and food safety. J. Am. Oil Chem. Soc. 83:473474.

Graham, J.G., Quinn, M.L., Fabricant, D.S. and Farnsworth, N.R. 2000. Plants used against cancer - an extension of the work of Jonathan Hartwell. J Ethno pharmacol.73(3):347-77.

Hussein, A.S., Alhadrami, G.A. and Khalil, Y.H. 1998. The use of dates and date pits in broiler starter and finisher diets. Bioresource Technology 66:219-223.

Shahidi, F. 2005. Bailey's Industrial Oil and Fat Products, Sixth Ed., Six Vol. Set. Copyright. John Wiley and Sons, Inc.

Van, G. 2005. Biodiesel Processing and Production. Fuel Processing Technology. Pp. 1097-1107.

\section{How to cite this article:}

Kirthy Reddy, M., H. Durga Rani, Ch. Naga Deepika, Suraj Samrawat, V. Akshara and Rajesh, K. 2017. Study on Physico-chemical Properties of Oil and Powder of Date Palm Seeds (Phoenix dactylifera). Int.J.Curr.Microbiol.App.Sci. 6(12): 486-492. doi: https://doi.org/10.20546/ijcmas.2017.612.059 